\title{
Yakıt Hücreli Araçlarda Enerji Yönetim Stratejileri ve Optimizasyon Hedeflerinin İncelenmesi
}

\author{
Ceyda Kök ${ }^{1 *}$, Suha Orçun Mert ${ }^{2}$ \\ 1*îskenderun Teknik Üniversitesi, Lisansüstü Eğitim Enstitüsü, Enerji Sistemleri Mühendisliği Bölümü, Hatay, Türkiye, (ORCID: 0000-0002-5536-3488), \\ ceydakok.ee19@iste.edu.tr \\ 2 İskenderun Teknik Üniversitesi, Mühendislik ve Doğa Bilimleri Fakültesi, Petrol ve Doğalgaz Mühendisliği Bölümü, Hatay, Türkiye (ORCID: 0000-0002-7721- \\ 1629), orcun.mert@iste.edu.tr
}

(2nd International Conference on Applied Engineering and Natural Sciences ICAENS 2022, March 10-13, 2022)

(DOI: 10.31590/ejosat.1070927)

ATIF/REFERENCE: Kök, C., Mert, S.O. (2022). Yakıt hücreli araçlarda enerji yönetim stratejileri ve optimizasyon hedeflerinin incelenmesi. Avrupa Bilim ve Teknoloji Dergisi, (34), 80-86.

$\ddot{O} \mathbf{z}$

Günümüzde enerji kullanımı çerçevesinde çevre kirliliği ön plana çıkmaktadır. Enerji kullanımı esnasında meydana gelen ve ekosisteme zarar veren bu kirlilikler, fosil yakıtların kullanımı oluşmaktadır. Çevre kirliliğinin sebepleri incelendiğinde; fosil yakıt kullanan içten yanmalı motorlu araçlardan kaynaklı emisyon gazlarının etkisinin önemli düzeyde olduğu görülmektedir. Bu nedenle, enerjinin verimli kullanımı ve çevresel faktörler dikkate alındığında yakıt hücreli elektrikli araçlar giderek yaygınlaşmaktadır. İçten yanmalı motorlu araçlar kadar hızlı ivmelenme beklentisinden dolayı bu araçlarda yakıt hücreleri batarya ve süperkapasitör ile birlikte kullanılmaktadır. Ancak bu araçlarda farklı güç kaynaklarının birlikte kullanımı ile karmaşık güç akışını yönetmek için enerji yönetim sistemlerine ihtiyaç duyulmaktadır. Enerji yönetimi stratejileri ise maksimum verim koşulları dikkate alınarak optimizasyon hedeflerine göre belirlenmektedir.

$\mathrm{Bu}$ çalışmada, yakıt hücreli araçların farklı enerji yönetim stratejileri incelenmiş olup; enerji yönetim sistemleri belirlenen üç hedef açısından detaylı olarak değerlendirilmiştir. Yapılan çalışma sonucu elde edilen bulgular, enerji yönetim sistemleri ve optimizasyon çalı̧̧malarını konu alan bilimsel ve sektörel faaliyetler için önem arz etmektedir.

Anahtar Kelimeler: Yakıt hücreli araçlar, Enerji yönetim sistemleri, Optimizasyon hedefleri, Yakıt hücresi, Batarya

\section{Investigation of Energy Management Strategies and Optimization Targets in Fuel Cell Vehicles}

\begin{abstract}
Today, environmental pollution comes to the fore in the framework of energy use. These pollutions, which occur during the use of energy and harm the ecosystem, are caused by the use of fossil fuels. When the causes of environmental pollution are examined; It is seen that the effect of emission gases originating from internal combustion engine vehicles using fossil fuels is at a significant level. For this reason, fuel cell electric vehicles are becoming increasingly common, considering the efficient use of energy and environmental factors. Due to the expectation of acceleration as fast as internal combustion engine vehicles, fuel cells are used with batteries and supercapacitors in these vehicles. However, energy management systems are needed to manage complex power flow with the use of different power sources together in these vehicles. Energy management strategies, on the other hand, are determined according to optimization targets, taking into account the maximum efficiency conditions.

In this study, different energy management strategies of fuel cell vehicles have been examined; energy management systems were evaluated in detail in terms of three objectives. The findings obtained as a result of the study are important for scientific and sectoral activities on energy management systems and optimization studies.
\end{abstract}

Keywords: Fuel cell vehicles, Energy management systems, Optimization targets, Fuel cell, Battery.

\footnotetext{
*Sorumlu Yazar: ceydakok.ee19@iste.edu.tr
} 


\section{Giriş}

Günümüzde sanayinin gelişmesi ve nüfusun artmasıyla birlikte enerji ihtiyacı giderek artmaktadır. $\mathrm{Bu}$ enerji ihtiyac1, güneş, rüzgar, dalga enerjisi gibi yenilenebilir enerji kaynakları ve fosil yakıtlar ile karşılanmaktadır. Geçmişten günümüze kadar birçok sektörde kullanılan fosil yakıtlar enerjinin yaklaşık \%80'nini sağlamaktadır [1]. Ancak fosil yakıtların kullanılmasıyla birlikte açığa iki temel sorun çıkmaktadır. $\mathrm{Bu}$ sorunlardan ilki fosil yakıt rezervlerinin sınırlı olmasından dolayı zamanla tükenmesidir. Diğeri ise küresel 1sınmaya, asit yağmurlarına, ozon incelmesine ve iklim değişikliklerine sebep olmasıdır. Fosil yakıtların en çok ulaşım sektöründe kullanıldığı açıkça bilinmektedir. Ulaşım hayatımızın vazgeçilmez bir parçası haline gelmiş ve taşıtlar günlük yaşantımızdaki hareketliliği kolaylaştırmıştır. Ancak içten yanmalı motorlu taşıtlar, karbondioksit (CO2), karbonmonoksit (CO), hidrokarbon (HC) gibi zararlı emisyonları açığa çıkarmaktadır [2]. Bu emisyonlar insan sağlığı ve çevre için önemli tehditler oluşturmaktadır. $\mathrm{Bu}$ nedenle, bilim insanları tarafından hem fosil yakıt tüketimini azaltmak hem de çevre kirliliğini engellemek için Elektrikli Araçlar(EA) ve Hibrit Elektrikli Araçları (HEA) çözüm olarak sunulmuştur.

Hibrit elektrikli araçlar, günümüz araçları ile bataryalı elektrikli araçlar arasında bir geçiş aracı olarak bilinmektedir. HEA, elektrik motoru ve içten yanmalı motordan oluşmaktadır, bu nedenle benzin ve dizel gibi fosil yakıtları kullanmaktadır. $\mathrm{Bu}$ araçlar sera gazı emisyonlarını azaltmış olsa da fosil yakıt kullandığ1 için istenilen çözüme ulaştıramamıştır. Bu nedenle, fosil yakıtları kullanmayan çevre dostu araçlar ülkelerin gündeminde yer almıştır. Bilim adamları, bu sorunları hafifletmek için Elektrikli Araçları önermişlerdir. EA'lar elektrik motoru ve bataryalardan oluşmaktadır, fosil yakıt kullanmadıkları için sıfır emisyona sahiptir. Bu araçlarda kullanılan Lityum İyon (Li-ion) bataryalar uzun raf ömrü, geniş çalışma aralığı, yüksek güç ve enerji yoğunluğu gibi birçok avantaja sahipken uzun şarj süresi, düşük menzil problemi ve şarj olanaklarının kısıtlı olması gibi dezavantajları vardır. Otomotiv endüstrisi, bu araçlara alternatif olarak daha kısa sürede şarj olabilen ve daha uzun menzile sahip Yakıt Hücreli Elektrikli Araçlar (YHEA) adlı yeni bir teknoloji geliştirmişlerdir.

YHEA, yakıt hücresinden gelen enerji ile beslenen elektrik motoru tarafından çalıştırılmaktadır. Bu araçlardaki birincil enerji taşıyıcısı hidrojendir. Hidrojen; hacimce çok düşük enerji içeriğine sahip olmasına rağmen, ağırlıkça bir yakıtın en yüksek içeriğine sahiptir. Bu yüksek içeriği sayesinde yakıt hücrelerinde ve roketlerde kullanılır. Fosil yakıtların aksine kullanıldıklarında sıfır emisyon oluşturmaktadır bu nedenle, geleceğin ulaşım yakıtı olarak öngörülmektedir [2].

Yakıt hücreleri, yakıttaki kimyasal enerjiyi elektrokimyasal tepkimelerle elektrik enerjisine dönüştürerek çalışırlar bu süreçte çevreye sadece su ve 1sı verirler. Yakıt hücreleri temiz ve verimli enerji üretim teknolojilerinden biri olarak kabul edildiğinden dolayı otomobillerde yaygın olarak kullanılmaktadır. Proton değişim membranlı yakıt hücreleri düşük çalışma sıcaklığı ve yüksek verim gibi avantajlara sahip olduğundan YHEA tercih edilmektedir. Ancak, Yakıt Hücre sistemleri yavaş dinamiklere sahip olduğu için hızlı güç geçişleri gaz açlığına yol açarak verimsizliklere ve hatta kalıcı hasara neden olabilmektedir. $\mathrm{Bu}$ nedenle, dinamik performansı iyileştirmek ve ömrünü uzatmak için bataryalar ve süperkapasitörler sisteme entegre edilerek sistem esnekliği ve performansı arttırılmaktadır [3].

Yakıt hücrelerinin batarya ve süperkapasitör ile birlikte kullanılmasının temel amaçları yakıt hücresinin boyutunu, hidrojen tüketimini ve maliyeti azaltmaktır [4]. YHEA'ların günümüz içten yanmalı motor tabanlı araçlara benzer güç yoğunluğuna ve başlangıca sahip olması beklenmektedir. Bu nedenle batarya rejeneratif fren enerjisi ile yakıt hücresine ek güç sağlamaktadır. Aynı zamanda YHEA'da birincil güç kaynağı olarak da kullanılabilmektedir [4]. Süperkapasitörler yüksek güç yoğunluğuna ve kısa süreli geçici yanıtlara sahip enerji depolama sistemi olduğundan dolayı araç uygulamalarında tercih edilmektedir. Yakıt hücresinin yavaş dinamiği ile süperkapasitörün hızlı yanıtı en yüksek gücü sağlamak amacıyla ideal bir seçim oluşturmaktadır.

Toyota, Honda, Hyundai gibi öncü otomobil sektörleri yakıt hücresi ve batarya hibrit sistemini kullanarak araç üretmeye başlamışlardır. Tablo 1'de YHEA'ların özeti gösterilmiştir.

Birden fazla güç kaynağına sahip araçlar hibrit araçlar olarak adlandırılır ve karmaşık güç akışına sahiptir. Talep edilen gücü farklı kaynaklar arasında bölüştürmek için enerji yönetim sistemine (EYS) ihtiyaç duyulmaktadır. EYS'nin hedefleri arasında yakıt ekonomisini iyileştirmek, emisyonları azaltmak, güvenirliliğini ve dayanıklılığını dikkate alarak enerji depolama sisteminin şarj durumunu ve ömrünü sürdürmek yer almaktadır. Yakıt hücreli araçlarda hidrojen tüketimini azaltmak, sistem ve batarya ömrünü uzatmak için EYS tasarlanmalıdır. EYS stratejileri literatürde farklı kontrol yöntemleri ile sınıflandırılmıştır. Ancak sınıflandırma genel olarak HEA hedeflerine yönelik olduğundan dolayı bu çalışmada YHEA optimizasyon hedefleri etrafında özetlenmiştir.

\section{Enerji Yönetim Sistemi}

Hibrit araçlar birden fazla güç kaynağı içerdiğinden dolayı karmaşık bir kontrol sistemine sahiptir. Kontrol algoritmalarının genel amacı; farklı güç kaynaklarını uygun çalışma modlarında ve yüksek verimle sürücü güç isteğini karş1layacak şekilde senkron olarak çalıştırmaktır.

Hibrit araçların kontrol stratejisi, üst seviye kontrol ve alt seviye kontrol stratejisi olmak üzere iki temel seviyede incelenmektedir. Alt seviye kontrol stratejisi, sürücünün tork talebine göre araç bileșenlerinin kontrolünü sağlamaktadır. Üst seviye kontrol stratejileri ise aracın tüm sistem üzerindeki kontrolünden sorumludur. Alt seviyeden gelen batarya doluluk oranı, sürücü güç talebi ve yol durumu geri dönüşlerini alan üst seviye kontrolü aracın çalışma moduna ve güç aktarım organları arasında verimli bir şekilde gücü paylaştırma gibi konulara karar verir.

Literatürde yer alan üst seviye kontrol sınıflandırması Şekil 1 'de gösterilmiştir. Enerji yönetim sistemleri genel olarak kural tabanlı ve optimizasyon tabanlı olmak üzere iki ayrı grupta incelenmektedir. Kural tabanlı stratejiler insan zekasına, matematiksel modellere dayalı olarak önceden sürüş döngüleri hakkında bilgisi olmadan belirlenmektedir [2]. Kural tabanl stratejiler kendi arasında deterministik kural tabanlı, bulanık kural tabanlı ve filtreleme tabanlı olmak üzere üç grupta incelenmektedir. Optimizasyon tabanlı stratejiler ise maliyet fonksiyonunu en aza indirmeyi amaçlamaktadır. Bu stratejiler gerçek zamanlı optimizasyon stratejisi ve küresel optimizasyon stratejisi olmak üzere ikiye ayrılmaktadır. 


\subsection{Kural Tabanlı Strateji}

\subsubsection{Deterministik Kural Tabanlı Strateji}

Deterministik kural tabanlı stratejiler, mühendislik deneyiminden yararlanarak önceden planlanmış tablolar aracılığıyla kullanılmaktadır. Bu stratejiler arasında termostat açma kapama yöntemi, yük takipçi stratejisi, durum makinesi kontrolü yer almaktadır [6].

Termostat açma kapama yöntemi, enerji depolama sistemi şarj durumu belirlenen eşiğin altında olduğunda yakıt hücresini maksimum verimlilik noktasında çalıştırarak enerji depolama sisteminin şarj edilmesine yardımcı olur. Şarj durumu üst seviyeye ulaştığında ise yakıt hücresini çalışmayı durdurur. Yakıt hücresinin sürekli açıp kapatmaktan dolayı bataryanın derin deşarjına yol açarak ömrünü kısaltır.

Yük takipçi stratejisi, talep edilen yakıt hücresi gücünün takip etmesi için güç kaynağını takip eden ve düzenleyen kontrol sistemidir Durum makinesi kontrol yöntemi, aracın çalışma modlarındaki geçişleri kontrol eden bir yöntemdir. Sürücü hız talebi, sürüş koşulları ve olası hatalarda sürüş modları değişmektedir. Mod geçişlerinde sürücünün taleplerini yerine getirebilme ve olası hatalara cevap verebilme yeteneğine sahiptir.

\subsubsection{Bulanık Tabanlı Kontrol Stratejisi}

Hibrit araçlar doğrusal olmayan, belirsiz ve zamanla değişen yapıya sahip olduğu için bulanık tabanlı kontrol stratejileri iyi bir alternatiftir. Kural tabanlı stratejiler kesin kurallar içermektedir, bulanı tabanlı kontrol stratejileri kesin sistemlere dayandırılmadığı için araç uygulamalarında esneklik sağlamaktadır. 'if-then' kuralına sahiptir ve durumları üyelik fonksiyonları ile tanımlanmaktadır. Bulanık kuralların tasarımı ve belirlenen üyelik fonksiyonları kullanıcı deneyimine bağlıdır. Yakıt ekonomisi ve enerji kaynaklarının kullanım ömrünü artırmak için bulanık tabanlı kontrol sistemleri optimizasyon tabanlı yaklaşımlar ile birlikte kullanılabilirler.

Bulanık mantık tabanlı kontrol yöntemleri, geleneksel, uyarlanabilir ve kestirimci olmak üzere üç grupta incelenmektedir. Geleneksel bulanık kontrol yöntemi, yakıt hücresinin daha verimli kullanılması için uygulanmaktadır. Verimliliğe veri setlerindeki giriș, çıkış ve bulanık kurallar ile karar vermektedir. Uyarlanabilir bulanık kontrol yöntemi, hibrit araçlar için optimize edilmesi gereken en önemli konuları ele almaktadır. Bunlar yakıt tüketimi, emisyon azaltımı, sürüş performansını artırma ve şarj durumunu en iyi hale getirmektir. Kestirimci bulanık mantık, önceden belirlenmiş sürüş çevrimlerini kullanarak hareket etmektedir. (Global Positioning System) GPS'den alınan veriler trafik yol durumu ve eğimlerde karşılaşacağı zorlukları içermektedir. Bu zorluklara karşı vereceği tepkiler öngörmek için tasarlanmıştır [7].

Tablo 1. Öncü otomobil sektörlerinin ürettiği YHEA'ların özellikleri [5]

\begin{tabular}{|c|c|c|c|c|c|c|}
\hline $\begin{array}{l}\text { YHEA } \\
\text { Modeli }\end{array}$ & Araç Görünümleri & $\begin{array}{l}\text { Araç } \\
\text { Gücü } \\
\text { (ps) }\end{array}$ & Yakit & $\begin{array}{c}\text { Yakit } \\
\text { Kapasitesi } \\
(\mathbf{k g})\end{array}$ & $\begin{array}{c}\text { Batarya } \\
\text { Kapasitesi } \\
(\mathbf{k W h})\end{array}$ & Menzil \\
\hline $\begin{array}{c}\text { Honda } \\
\text { Clarity } \\
\text { Fuel cell } \\
2017\end{array}$ & & 174 & $\mathrm{H}_{2}$ & 5 & - & 589 \\
\hline $\begin{array}{l}\text { Hyundai } \\
\text { NEXO } \\
2019\end{array}$ & & 163 & $\mathrm{H}_{2}$ & 6.3 & 1.56 & 611 \\
\hline $\begin{array}{l}\text { Mercedes- } \\
\text { Benz } \\
\text { GLC F- } \\
\text { CELL }\end{array}$ & & 211 & $\mathrm{H}_{2}$ & 4.4 & 13.5 & 478 \\
\hline $\begin{array}{c}\text { Audi } \\
\text { A7 } \\
\text { Sportback } \\
\text { h-tron } \\
\text { quattro }\end{array}$ & & 220 & $\mathrm{H}_{2}$ & 5 & 8.8 & 500 \\
\hline $\begin{array}{l}\text { Nissan e- } \\
\text { Bio } \\
\text { Fuel-Cell }\end{array}$ & & - & $\mathrm{CH}_{3} \mathrm{CH}_{2} \mathrm{OH}$ & - & 24 & 600 \\
\hline
\end{tabular}




\subsubsection{Filtreleme Tabanlt Strateji}

Filtreleme tabanlı strateji, aracın toplam yük gücünü düşük ve yüksek frekans gücü olarak iki grupta incelemektedir. Düşük frekans gücü yakıt hücresi tarafından karşılanırken, yüksek frekans gücü diğer enerji kaynakları tarafından karşılanmaktadır.

\subsection{Optimizasyon Tabanlı Strateji}

Optimizasyon tabanlı stratejilerin amacı yakıt ekonomisi ve maliyet fonksiyonunu en aza indirgemektir. Kontrol sisteminin ve araçtaki güç kaynaklarının doğru ve verimli çalışması için optimizasyon problemlerindeki kısıtlamaları dikkate almaktadır [6].

\subsubsection{Küresel Optimizasyon Stratejisi}

Küresel optimizasyon stratejisi, yol durum bilgisi ile birlikte güç kaynaklarının optimum çalışabilmesini hesaplamaktadır. Gerçek bir sürüş döngüsünü elde etmek kolay olmadığından dolayı hesaplama yükü büyüktür. $\mathrm{Bu}$ durum bu küresel optimizasyon stratejisini deneysel olarak elde edilmesini zorlaştırmaktadır.

Dinamik programlama, hem bilgisayar programlama yöntemi hem de matematiksel optimizasyon yöntemi olduğundan dolayı karmaşık bir problemi öz yinelemeli bir şekilde en basite indirgeyerek çözmeyi hedeflemektedir. Bu stratejide önceden tanımlanmış görev döngüsü bilgisi gerekli olduğundan dolayı gerçek zamanlı uygulanamamaktadır. Kontrolörleri formüle etmek ve ayarlamak için kullanılmaktadır.

Genetik algoritma, optimizasyon ile en iyi sonuca ulaşmak için kullanılır ve Darwin teorisine dayanmaktadır. Popülasyon adı verilen aday çözümler yeni optimal popülasyon oluşturmak için geliştirilirler. Optimum çözüm bulunana kadar iterasyona devam etmektedir.
Parçacık sürü optimizasyonu, doğrusal olmayan sistemler için geliştirilmiş olan bu teknik hızlı, ucuz, sağlam bir optimazyon tekniğidir. Doğadaki kuş sürülerinden esinlenerek geliştirilen buluşsal bir yöntemdir. Popülasyon ile başlayarak yinelemeli yöntem ile en optimal çözüm bulunana kadar devam etmektedir.

\subsubsection{Gerçek Zamanlı Optimizasyon}

Gerçek zamanlı optimizasyonda, küresel optimizasyon sorununu gerçek zamanlı optimizasyona dönüştürmek için maliyet fonksiyonunu gerçek zamanlı olarak minimize ederek eşdeğer maliyet fonksiyonu oluşturur. Bunu farklı güç kaynakları arasında anlık güç paylaşımı hesaplamak için yapmaktadır.

Eşdeğer yakıt tüketimi stratejisi, enerji depolama sistemlerinde depolanan enerjiyi elektrik enerjisinden eşdeğer hidrojen tüketimine dönüştürür. Bu strateji aracın hem hidrojen tüketimini hem de eşdeğer hidrojen tüketimini en aza indirgemeyi hedeflemektedir. Sürüş döngüsünden ve batarya SOC sınırlarından etkilenen eşdeğer faktör bu strateji için oldukça önemlidir. Eşdeğer faktör ayarlanarak yakıt tüketimini azaltmanın yanında aynı zamanda güç kaynaklarının ömrünü de uzatabilmektedir.

Pontryagin'in minimum ilkesi, kısıtlamaların varlığında bir durum ya da girdi kontrolünü sağlarken mümkün olan en iyi sonucu sağlamaktadır. $\mathrm{Bu}$ işlem sonucunda optimizasyonu dinamik programlamaya daha yakın olmaktadır.

Model kestirimci kontrolü, içinde bulunduğu zaman dilimi ile birlikte gelecekteki zaman dlimini de hesaba katarak optimize edebilmektedir. $\mathrm{Bu}$ durum yalnızca mevcut zaman aralığını kullanarak elde edilmektedir. $\mathrm{Bu}$ strateji gelebilecek olayları önceden tahmin ederek kontrol önlemlerini alabilir.

Optimal kontrol teorisi, matematiksel bir optimizasyon yaklaşımıdır. Uyarlanabilir kontrol algoritmasına sahiptir, yakıt tüketimini en aza indirgeyebilir.

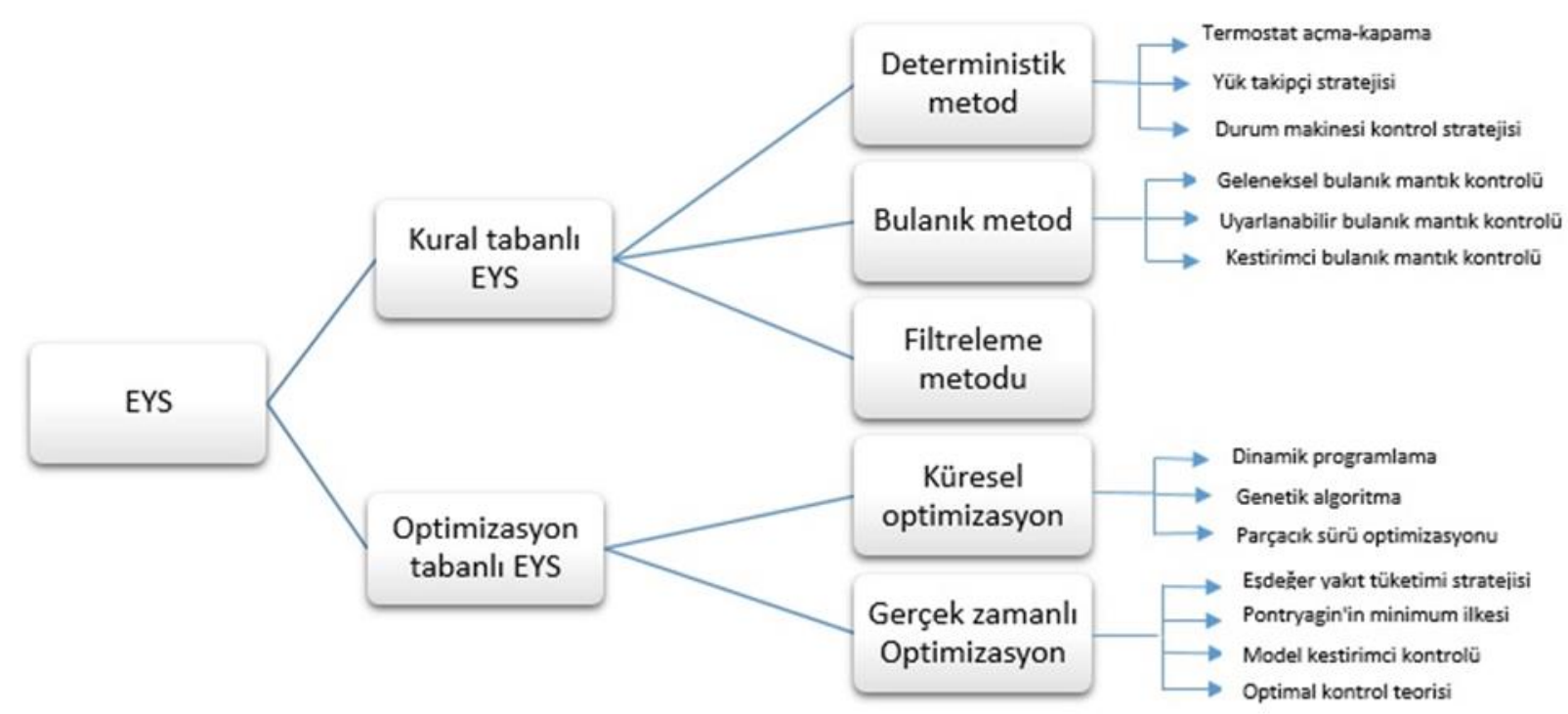

Şekil 1. Üst seviye kontrol sınıflandırması 


\section{Yakıt Hücreli Hibrit Araçlarda Enerji Yönetim Sistemi Hedefleri}

Yakıt hücreli araçların günümüz içten yanmalı araçlar ve hibrit araçlarla rekabet edebilmesi için aracın maliyetini azaltmak ve güç kaynaklarının dayanıklılığını artırmak hedeflenmektedir [8]. YHEA'da, sürücünün isteklerine göre talep edilen gücü karşılarken hidrojen tüketiminin en aza indirgeyip, yakıt hücresi ve bataryanın ömrünü artırmayı hedeflen EYS tasarlamak karşılaşılan zorluklardan biridir. Tüm hedeflere aynı anda ulaşmak zor olacağından dolayı, yalnızca bir hedef seçmek ya da belirli hedefler arasında seçim yapmak en popüler yöntemdir. Şekil 2'de EYS stratejilerinin yakıt hücresi ömrü, batarya ömrü ve yakıt tüketimi hedeflerine uygunluğu özetlenmiştir. Enerji yönetim sistemlerinin farklı hedeflerde kullanımı Tablo 2'de listelenmiştir.

Enerji Tüketimi: Yakıt hücresini verimli aralıkta ve bataryayı yeterli şarjda çalıştıran kontrol algoritması tasarlandığında YHEA enerji tüketimi azaltma hedefine ulaşılmaktadır.

Yakıt Hücresi Ömrü: Yakıt hücresinin sık açılıp kapanmasını önleyen ve voltajını makul bir çalışma aralığında tutan kontrol algoritması ile yakıt hücresi ömrü artırılmaktadır.
Batarya Ömrü: Batarya sıcaklık, akım ve derinlik deşarjı gibi özelliklerden etkilenmektedir. Bu nedenle, EYS batarya ömrünü artırmak için pil gücünü ve deşarj derinliği ile ilgilenmektedir.

Kural tabanlı stratejiler, yakıt tüketimi ve güç kaynaklarının kullanım ömrünü hedefleri olan denetim stratejisidir. Yakıt hücresinin yüksek verimlilik bölgesinde çalıșmasını sağlamak ve güç kaynaklarının ömrünü ve verimliliğini artırmak için sistemleri denetler ve kisitlamalar getirmektedir. Deterministik kural tabanlı strateji ve bulanık mantık stratejisi yakıt tüketimini azaltmak ve güç kaynaklarının performansını artırmak için iş birliği yapmaktadır. Filtreleme tabanlı stratejiler, yakıt hücresinin ve bataryanın kullanım ömürlerini artırmak için tercih edilen stratejilerdendir.

Optimizasyon tabanlı stratejiler yakıt tüketimi ve güç kaynaklarının kullanım ömrünü ölçmek maliyet fonksiyonunu kullanabilir aynı zamanda yakıt tüketimini azaltmak ve dayanıklılığı artırmak için güç kaynaklarına sınırlamalar getirebilir. Küresel optimizasyon stratejisi tıpkı gerçek zamanlı optimizasyon stratejisi gibi amaç fonksiyonundan yararlanır ve amacına ulaşmak için güç kaynaklarına sınırlamalar getirir.
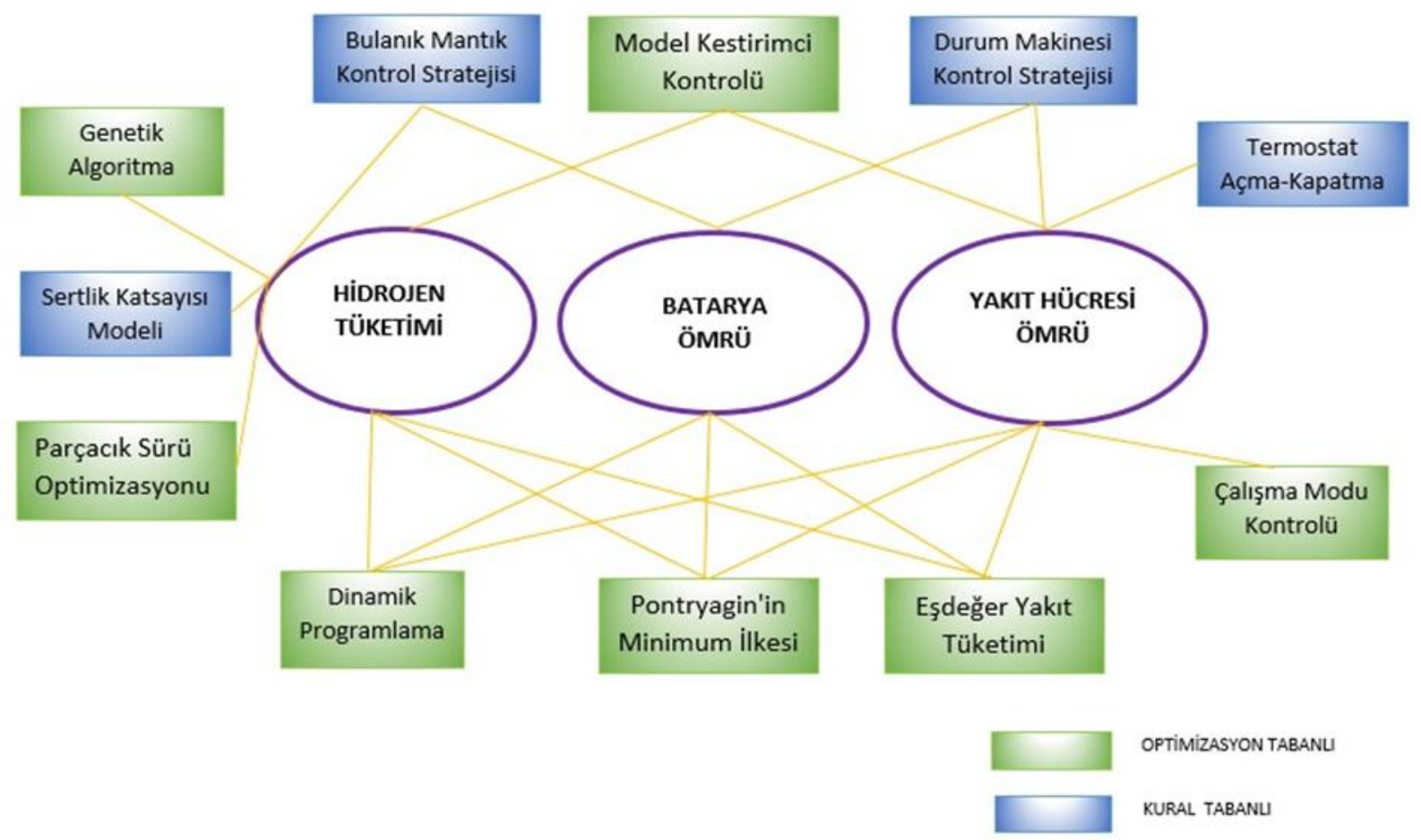

Şekil 2. EYS hedefleri 
Tablo 2. Amaçlarına göre enerji yönetim sistemleri

\begin{tabular}{|c|c|c|c|c|}
\hline & \multirow{2}{*}{ Hidrojen Tüketimi } & \multirow{2}{*}{ Batarya Ömrü } & \multirow{2}{*}{ Yakıt Hücresi Ömrü } \\
\hline & & & & \\
\hline \multirow{4}{*}{ 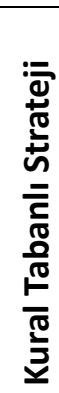 } & Çalışma Modu Kontrolü & & & [9],[10] \\
\hline & Durum makinesi kontrol stratejisi & & [11] & {$[11]$} \\
\hline & Sertlik Katsayısı Modeli & [12] & & \\
\hline & Bulanık Mantık Kontrolü & {$[13],[14]$} & {$[15],[16]$} & \\
\hline \multirow{6}{*}{ 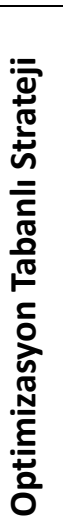 } & Pontryagin'in minimum ilkesi & {$[17],[18],[19]$} & {$[17],[19]$} & {$[17]$} \\
\hline & Eşdeğer tüketim minimizasyon stratejisi & {$[21],[23]$} & [21] & {$[20],[22]$} \\
\hline & Model Kestirimci Kontrolü & {$[24],[25]$} & & [25] \\
\hline & Dinamik Programlama & {$[26],[27],[28],[29]$} & {$[26],[28]$} & [26],[29] \\
\hline & Genetik Algoritma & {$[30],[31]$} & & \\
\hline & Parçacık Sürü Optimizasyonu & {$[32],[33]$} & & \\
\hline
\end{tabular}

\section{Sonuçlar}

Yakıt hücreli araçlardan beklenen yüksek performans için enerji yönetim stratejileri kilit rol oynamaktadır. Enerji yönetim stratejileri belirlenen hedeflere göre seçilmelidir. İstenilen hedeflere göre aracın talep edilen gücünü karşılaması için enerji yönetim stratejileri ve bu stratejilere uygun kontrol şemaları oluşturulmalıdır. Birçok çalışmada enerji yönetim stratejileri ve yakıt tüketimi hedefi ele alınmaktadır. Ancak yakıt hücreli araçlar genellikle bataryalarla birlikte kullandıkları için batarya ve yakıt hücresi ömrü de oldukça önemlidir. Bu çalışmada, enerji yönetim stratejilerinin özellikleri yakıt tüketimini azaltma, batarya ve yakıt hücresi ömrünü artırma hedeflerine göre sınıflandırılmıştır.

\section{Teșekkür}

Bir numaralı yazar, YÖK 100/2000 Elektrikli ve Hibrit Araçlar Doktora Programı bursuyla desteklenmektedir.

\section{Kaynakça}

[1].Sorlei, I. S., Bizon, N., Thounthong, P., Varlam, M., Carcadea, E., Culcer, M., ... \& Raceanu, M. (2021). Fuel cell electric vehicles-A brief review of current topologies and energy management strategies. Energies, 14(1), 252.

[2].Panday, A., \& Bansal, H. O. (2014). A review of optimal energy management strategies for hybrid electric vehicle. International Journal of Vehicular Technology, 2014.

[3]. Sulaiman, N., Hannan, M. A., Mohamed, A., Ker, P. J., Majlan, E. H., \& Daud, W. W. (2018). Optimization of energy management system for fuel-cell hybrid electric vehicles:
Issues and recommendations. Applied energy, 228, 20612079.

[4]. Xu, L., Li, J., Ouyang, M., Hua, J., \& Yang, G. (2014). Multimode control strategy for fuel cell electric vehicles regarding fuel economy and durability. International Journal of Hydrogen Energy, 39(5), 2374-2389.

[5]. Teng, T., Zhang, X., Dong, H., \& Xue, Q. (2020). A comprehensive review of energy management optimization strategies for fuel cell passenger vehicle. International Journal of Hydrogen Energy, 45(39), 20293-20303.

[6]. Li, H., Ravey, A., N'Diaye, A., \& Djerdir, A. (2017, December). A review of energy management strategy for fuel cell hybrid electric vehicle. In 2017 IEEE Vehicle Power and Propulsion Conference (VPPC) (pp. 1-6). IEEE.

[7]. İnci, M., Büyük, M., Demir, M. H., \& İlbey, G. (2021). A review and research on fuel cell electric vehicles: Topologies, power electronic converters, energy management methods, technical challenges, marketing and future aspects. Renewable and Sustainable Energy Reviews, 137, 110648

[8]. Pollet, B. G., Staffell, I., \& Shang, J. L. (2012). Current status of hybrid, battery and fuel cell electric vehicles: From electrochemistry to market prospects. Electrochimica Acta, 84, 235-249.

[9]. Aouzellag, H., Ghedamsi, K., \& Aouzellag, D. (2015). Energy management and fault tolerant control strategies for fuel cell/ultra-capacitor hybrid electric vehicles to enhance autonomy, efficiency and life time of the fuel cell system. International journal of hydrogen energy, 40(22), 7204-7213.

[10].Lachhab, I., \& Krichen, L. (2014). An improved energy management strategy for $\mathrm{FC} / \mathrm{UC}$ hybrid electric vehicles 
propelled by motor-wheels. International journal of hydrogen energy, 39(1), 571-581.

[11]. Li, Q., Yang, H., Han, Y., Li, M., \& Chen, W. (2016). A state machine strategy based on droop control for an energy management system of PEMFC-battery-supercapacitor hybrid tramway. International Journal of Hydrogen Energy, 41(36), 16148-16159.

[12]. Yun, H., Liu, S., Zhao, Y., Xie, J., Liu, C., Hou, Z., \& Wang, K. (2015). Energy management for fuel cell hybrid vehicles based on a stiffness coefficient model. International Journal of Hydrogen Energy, 40(1), 633-641.

[13]. Li, Q., Chen, W., Li, Y., Liu, S., \& Huang, J. (2012). Energy management strategy for fuel cell/battery/ultracapacitor hybrid vehicle based on fuzzy logic. International Journal of Electrical Power \& Energy Systems, 43(1), 514-525.

[14]. Mohammedi, M., Kraa, O., Becherif, M., Aboubou, A., Ayad, M. Y., \& Bahri, M. (2014). Fuzzy logic and passivitybased controller applied to electric vehicle using fuel cell and supercapacitors hybrid source. Energy Procedia, 50, 619626.

[15]. Hwang, J. J., Hu, J. S., \& Lin, C. H. (2015). Design of a range extension strategy for power decentralized fuel cell/battery electric vehicles. International Journal of Hydrogen Energy, 40(35), 11704-11712.

[16]. Saib, S., Hamouda, Z., \& Marouani, K. (2017, October). Energy management in a fuel cell hybrid electric vehicle using a fuzzy logic approach. In 2017 5th International Conference on Electrical Engineering-Boumerdes (ICEEB) (pp. 1-4). IEEE.

[17]. Xu, L., Li, J., Ouyang, M., Hua, J., \& Yang, G. (2014). Multi-mode control strategy for fuel cell electric vehicles regarding fuel economy and durability. International Journal of Hydrogen Energy, 39(5), 2374-2389.

[18]. Zheng, C. H., Xu, G. Q., Park, Y. I., Lim, W. S., \& Cha, S. W. (2014). Prolonging fuel cell stack lifetime based on Pontryagin's Minimum Principle in fuel cell hybrid vehicles and its economic influence evaluation. Journal of Power Sources, 248, 533-544.

[19].Ettihir, K., Boulon, L., \& Agbossou, K. (2016). Optimization-based energy management strategy for a fuel cell/battery hybrid power system. Applied Energy, 163, 142153.

[20]. Tian, H., Wang, X., Lu, Z., Huang, Y., \& Tian, G. (2017). Adaptive fuzzy logic energy management strategy based on reasonable SOC reference curve for online control of plug-in hybrid electric city bus. IEEE Transactions on Intelligent Transportation Systems, 19(5), 1607-1617.

[21]. Han, J., Park, Y., \& Park, Y. S. (2012). A novel updating method of equivalent factor in ECMS for prolonging the lifetime of battery in fuel cell hybrid electric vehicle. IFAC Proceedings Volumes, 45(30), 227-232.

[22]. Geng, B., Mills, J. K., \& Sun, D. (2011). Two-stage energy management control of fuel cell plug-in hybrid electric vehicles considering fuel cell longevity. IEEE Transactions on vehicular technology, 61(2), 498-508.

[23]. Aiteur, I. E., Vlad, C., \& Godoy, E. (2015, October). Energy management and control of a fuel cell/supercapacitor multisource system for electric vehicles. In 2015 19th International Conference on System Theory, Control and Computing (ICSTCC) (pp. 797-802). IEEE.

[24]. Zhang, S., Luo, Y., Li, K., \& Wang, J. (2017, May). Predictive energy management strategy for fully electric vehicles based on hybrid model predictive control. In 2017 American Control Conference (ACC) (pp. 3625-3630). IEEE.

[25]. Torreglosa, J. P., Garcia, P., Fernández, L. M., \& Jurado, F. (2013). Predictive control for the energy management of a fuel-cell-battery-supercapacitor tramway. IEEE Transactions on Industrial Informatics, 10(1), 276-285.

[26]. Fares, D., Chedid, R., Panik, F., Karaki, S., \& Jabr, R. (2015). Dynamic programming technique for optimizing fuel cell hybrid vehicles. International Journal of Hydrogen Energy, 40(24), 7777-7790.

[27]. Zhou, W., Yang, L., Cai, Y., \& Ying, T. (2018). Dynamic programming for New Energy Vehicles based on their work modes part I: Electric Vehicles and Hybrid Electric Vehicles. Journal of power sources, 406, 151-166.

[28]. Martel, F., Kelouwani, S., Dubé, Y., \& Agbossou, K. (2015). Optimal economy-based battery degradation management dynamics for fuel-cell plug-in hybrid electric vehicles. Journal of Power Sources, 274, 367-381.

[29]. Martel, F., Dubé, Y., Kelouwani, S., Jaguemont, J., \& Agbossou, K. (2016). Long-term assessment of economic plug-in hybrid electric vehicle battery lifetime degradation management through near optimal fuel cell load sharing. Journal of Power Sources, 318, 270-282.

[30].Odeim, F., Roes, J., \& Heinzel, A. (2015). Power management optimization of an experimental fuel cell/battery/supercapacitor hybrid system. Energies, 8(7), 6302-6327.

[31]. Fernández, R. Á., Caraballo, S. C., Cilleruelo, F. B., \& Lozano, J. A. (2018). Fuel optimization strategy for hydrogen fuel cell range extender vehicles applying genetic algorithms. Renewable and sustainable energy reviews, 81, 655-668.

[32]. Kandi Dayeni, M., \& Soleymani, M. (2016). Intelligent energy management of a fuel cell vehicle based on traffic condition recognition. Clean Technologies and Environmental Policy, 18(6), 1945-1960.

[33]. Habib, M., Khoucha, F., Benbouzid, M. E. H., \& Kheloui, A. (2015). Rule-Based Energy Management Strategy Optimized Using PSO for Fuel Cell/Battery Electric Vehicle. 